\title{
Pengembangan Learning Object pada Training Basic di PT.Circleka Indonesia Utama
}

\author{
Rafii Ramandika Yudhoyono, ${ }^{1 \rrbracket}$ Mulyadi $^{2}$, Kunto Imbar Nursetyo ${ }^{2}$ \\ ${ }^{1}$ Universitas Negeri Jakarta, Jakarta, Indonesia. \\ ${ }^{2}$ Universitas Negeri Jakarta, Jakarta, Indonesia. \\ 3 Universitas Negeri Jakarta, Jakarta, Indonesia. \\ DOI: https://doi.org/10.21009/JPI.031.05
}

\begin{tabular}{l} 
Article History \\
\hline Received : 2020 \\
Accepted : 2020 \\
Published : 2020 \\
\hline Keywords \\
\hline Development, \\
Learning Object, \\
Training Basic, Rapid \\
Prototyping
\end{tabular}

\begin{abstract}
Pengembangan ini bertujuan untuk menghasilkan produk berupa Learning Object pada Training Basic di PT.Circleka Indonesia Utama. Produk Learning Object ini difokuskan pada pengembangan video pembelajaran mengacu pada model Rapid Prototyping yang memiliki lima tahap antara lain Assess Needs and Analyze Content, Set Objectives, Construct Prototype (design), Utilization Prototype (research), dan Installing the Final System. Produk Learning Object ini telah melalui tahap evaluasi yang melibatkan para ahli dan pengguna (Customer Service Representative Circle K). Hasil uji coba expert review yang diperoleh dari ahli materi sebesar 3,56 (sangat baik), ahli desain pembelajaran, ahli media pembelajaran 3,49 (sangat baik). Kemudian pada tahap uji coba pengguna (one-to-one evaluation) memperoleh nilai 3,20 (baik) dan (small group evaluation) dengan nilai 3,49 (sangat baik). Hasil evaluasi formatif menunjukan bahwa produk Learning Object ini dapat digunakan pada Training Basic Circle K sebagai bagian dari Store Development Program (SDP) PT. Circleka Indonesia Utama.
\end{abstract}

\begin{abstract}
This development aims to produce products in the form of Learning Objects in Basic Training at PT.Circleka Indonesia Utama. This Learning Object product is focused on developing learning videos referring to the Rapid Prototyping model which has five stages including Assess Needs and Analyze Content, Set Objectives, Construct Prototype (design), Utilization Prototype (research), and Installing the Final System. This Learning Object product has gone through an evaluation phase involving experts and users (Customer Service Representative Circle K). The results of expert review trials obtained from material experts were 3.56 (very good), learning design experts, learning media experts 3.49 (very good). Then in the user trial phase (one-to-one evaluation) obtained a value of 3.20 (good) and (small group evaluation) with a value of 3.49 (very good). Formative evaluation results show that this Learning Object product can be used in Basic Circle K Training as part of the PT Development Store Program (SDP). Circleka Indonesia Utama.
\end{abstract}




\section{PENDAHULUAN}

Pengelolaan sumber daya manusia saat ini mulai mendapat perhatian khusus terutama pada perusahaan yang memiliki kebutuhan mendesak akan sumber daya manusia (SDM) yang berkompeten. Hal ini dilakukan karena SDM merupakan salah satu aset terpenting dalam sebuah perusahaan. Untuk itu diperlukan pengelolaan SDM yang terorganisir guna membekali dan meningkatkan kompetensi mereka. Salah satu intervensi untuk membekali dan meningkatkan kompetensi SDM yaitu melalui sebuah pelatihan. Pelatihan diharapkan dapat membekali karyawan dalam melaksanakan pekerjaannya. Menurut Walter Dick dkk (2009) yang mendefinisikan pelatihan sebagai "...A prespecied and planned experience that enable a person to do something that he or she could not do before."

Menurut Walter Dick, pelatihan merupakan pengalaman yang dirancang untuk membekali seseorang atas pengetahuan dan keterampilan yang belum dimilikinya. Salah satu perusahaan swasta yang sangat memperhatikan Pengembangkan Sumber Daya Manusia-nya adalah PT. Circleka Indonesia Utama. Perusahaan yang bergerak dibidang ritel tersebut memiliki beberapa program development karyawan diantaranya SDP (Store Development Program), ODP (Operational Development Program), GMDP (General Manager Development Program). Namun dalam penelitian kali ini peneliti hanya berfokus kepada SDP untuk karyawan toko karena program ini termasuk program development yang paling sering dilakukan dan paling dibutuhkan oleh perusahaan.

PT. Circleka Indonesia Utama merupakan salah satu perusahaan yang sangat selektif dalam memilih karyawan baru khususnya di bagian operasional toko. Terdapat beberapa tahap seleksi pada SDP di PT. Cicleka Indonesia Utama. Tahap yang pertama dilakukan yaitu proses Psikotes dan Interview calon pegawai yang dilakukan oleh tim rekrutmen dari masing-masing cabang. Tahap kedua yaitu Training Basic yaitu merupakan pelatihan yang memberikan pengetahuan dan keterampilan terkait kompetensi dasar kepada calon karyawan toko level Pramuniaga atau Customer Service Representative (CSR). Materi yang tersaji pada Training Basic antara lain adalah Standar Penampilan CSR, Prinsip pelayanan terhadap customer, Pemajangan barang dan kebersihan toko. Pelatihan dilakukan selama 3 hari dengan durasi pelatihan 7 jam per harinya. Tahap terakhir yaitu Field Training. Pada tahap ini para calon karyawan diminta untuk melakukan simulasi pekerjaan yang telah diberikan pada Training Basic. Field Taining dilakukan pada toko-toko yang telah dipilih sebagai toko mentor atau toko yang memiliki fasilitas memadai untuk dilakukannya Field Training. Setelah calon karyawan melalui tahap - tahap tersebut, tim rekrutmen akan menentukan karyawan yang terseleksi dan melakukan penempatan CSR sesuai dengan toko - toko yang membutuhkan.

Proses rekrutmen ini berlangsung selama tujuh hari. Terbagi menjadi satu hari pada tahap Psikotes dan Interview, tiga hari pada tahap Training Basic dan tiga hari pada tahap Field Training. Proses rekrutmen ini dilakukan di kantor cabang yang saat ini terdapat sembilan cabang di seluruh Indonesia, diantaranya Jakarta, Bali, Bandung, Yogyakarta, Surabaya, Makassar, Batam, Medan, Palembang.

Berdasarkan hasil wawancara tidak terstruktur dengan Learning Development Coordinator PT. Circleka Indonesia Utama, peneliti menemukan beberapa kesenjangan dalam tahap kedua SDP yaitu Training Basic di PT.Circleka Indonesia Utama. Kesenjangan tersebut merupakan masalah yang menghambat proses rekrutmen pada PT Circleka Indonesia Utama baik dari segi efisiensi waktu maupun penyampaian materi.

Fakta kesenjangan yang pertama yaitu, Training Basic dilakukan selama tiga hari, sedangkan proses pemenuhan karyawan membutuhkan waktu yang lebih cepat karena turn over karyawan yang tinggi. Berdasarkan data turn over karyawan toko dalam tiga tahun terakhir, pada tahun 2016 karyawan toko yang putus kontrak mencapai $8,3 \%$ setiap bulannya. Tahun 2017 mencapai $9,6 \%$ setiap bulannya. Tahun 2018 mencapai $8,0 \%$ setiap bulannya. Dalam hal ini, proses rekrutmen harus dilakukan lebih cepat untuk memenuhi kebutuhan jumlah karyawan toko.

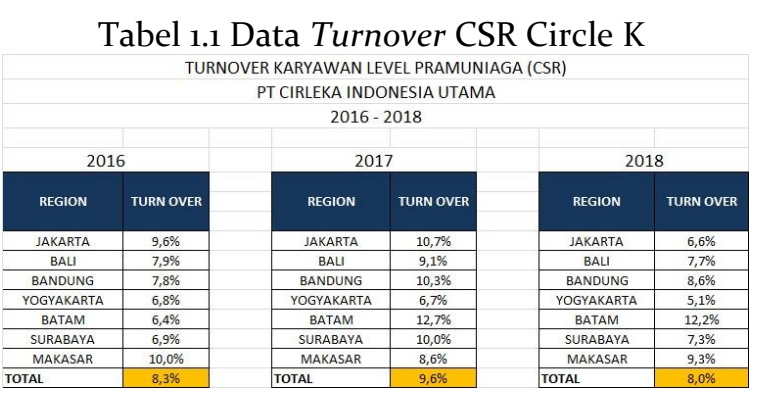

Hal ini juga berpengaruh terhadap biaya yang di keluarkan. Setiap tahunnya di butuhkan sekitar 48 kali pelatihan di 9 region, dengan biaya yang dikeluarkan setiap sekali pelatihan mencapai Rp. 500.ooo. Jadi pengeluaran untuk Training Basic diperkirakan mencapai Rp. 216.0oo.ooo / tahun. Karena materi pelatihan bersifat umum dan berulang maka perlu dipertimbangkan metode yang tepat untuk memangkas biaya pelatihan yang cukup besar tersebut.

Fakta kesenjangan yang kedua yaitu materi pelatihan yang tidak terstandarisasi. Modul yang digunakan sebagai bahan ajar pada training basic sudah tidak relevan digunakan. Pada akhirnya awal 
tahun 2018 dikembangkan modul pelatihan yang sudah terstandariasi dari kantor pusat untuk dijadikan modul pelatihan yang baru dalam Training Basic. Setelah diperbarui, muncul kesenjangan baru yaitu modul ini tidak digunakan oleh para trainer dengan berbagai alasan seperti, materi pada modul sulit dipahami, modul sulit untuk dimanfaatkan dan kendala dalam mengunduhnya dikarenakan jaringan yang kurang baik.

Fakta kesenjangan yang ketiga yaitu sudah tersedianya paltform e-learning menggunakan moodle yang digunakan sebagai solusi untuk mengatasi kesenjangan sebelumnya. Namun platform ini belum digunakan secara optimal dalam proses pembelajaran. Pemanfaatan platform ini hanya sebatas tempat meletakan materi - materi pelatihan untuk diunduh oleh peserta pelatihan sebelum memulai pelatihan. Dari segi SDM perusahaan pun sudah siap untuk mengelola platform. Terdapat bagian IT yang mengelola server e - learning dan bagian human resource general affair sendiri yang akan mengelola Learning Management System (LMS). Namun materi yang disajikan pada platform $e$ - learning hanya berbentuk teks format pdf.

Konten pembelajaran online sebaiknya harus memuat Learning Object yang memungkinkan peserta pelatihan mendapatkan sumber belajar yang lebih menarik, variatif dan sesuai dengan karakteristik mereka. Melalui pembelajaran online yang optimal, kesenjangan - kesenjangan yang ada dapat teratasi. Pembelajaran online dapat mempersingkat proses seleksi karyawan toko. Training basic yang awalnya dilakukan di dalam kelas selama 3 hari dapat disingkat menjadi 1 hari. Pembelajaran online juga dapat memangkas biaya pelatihan. Perusahan tidak perlu mengeluarkan biaya untuk logistik peserta dan trainer karena training di lakukan secara online. Selain itu Learning Object dalam pembelajaran online dapat mengubah fungsi trainer menjadi fasilitator saat pendalaman materi yang dilakukan pada field training. intervensi ini juga dapat mengatasi masalah standarisasi materi training basic. Melalui pengembangan learning object dalam pembelajaran online materi terpusat pada satu tempat, dengan begitu materi pelatihan yang diberikan pada setiap regional akan sama dan perusahaan hanya akan mengontrol kesesuaian materi pelatihan pada satu titik (Sentralisasi). Berdasarkan fakta - fakta tersebut, peneliti berniat untuk mengembangkan Learning Object pada Training Basic di PT. Circleka Indonesia Utama. Intervensi ini diharapkan dapat mengatasi kesenjangan yang ada pada proses rekrutmen di PT. Circleka Indonesia Utama.

\section{METODE}

Pengembangan learning object ini menggunakan model Rapid Prototyping. Terdapat 5 tahap yang menjadi tujuan khusus pada penelitian pengembangan ini yaitu (1) Melakukan analisis kebutuhan peserta trainging basic dan analisis materi yang akan dikembangkan pada learning object. (2) Menentukan tujuan pembelajaran online pada training basic. (3) Mengembangkan prototipe yang sesuai dengan hasil analisis kebutuhan dan tujuan pembelajaran. (4) Melakukan uji coba dan evaluasi prototipe yang telah dikembangkan dan diuji cobakan pada ahli (ahli desain pembelajaran, ahli materi, ahli media) dan pengguna. (5) Menghasilkan produk learning object kemudian mengunggah kedalam platform e-learning.

Tahap pertama yaitu analisis kebutuhan (assess need) Pada tahap ini peneliti melakukan beberapa analisis terkait dengan kemampuan awal dan karakteristik peserta pelatihan. Pada tahap ini data didapat dengan menyebar kuisioner yang disebar kepada peserta training basic. Tujuan dari analisis ini adalah untuk mendapatkan informasiinformasi terkait karakteristik peserta pelatihan sebagai acuan dalam mengembangkan produk.

Pada langkah ini peneliti menentukan sasaran dalam penelitian ini yaitu karyawan yang baru saja bergabung dengan PT. Circleka Indonesia Utama dan sedang menjalani Training Basic. Penentuan ini di dasari dengan syarat utama sdm yang terkualifikasi pada persyaratan calon karyawan PT. Circleka Indonesia Utama. Kemudian langkah berikutnya adalah menyiapakan strategi untuk mengumpulkan data.

Untuk melakukan pengumpulan data peneliti menyebar kuisioner terhadap beberapa peserta pelatihan. Pertanyaan dalam kuisioner berisi pertanyaan terkait dengan karakteristik peserta peltihan meliputi pengetahuan tentang materi pelatihan ; penggunaan teknologi komputer dan internet ; penggunaan pembelajaran online.

Kemudian langkah selanjutnya yaitu peneliti melakukan analisis terhadap data yang sudah didapat sebelumnya melalui pengisian kuisioner. Analisis data dilakukan dengan cara mengkaji jawaban setiap butir pertanyaan yang sudah dijawab oleh masing-masing sasaran kemudian membuat kesimpulan. Terakhir, peneliti membuat laporan dari hasil analisis yang telah dilakukan.

Tahap selanjutnya adalah analisis konten (analyze content). Dalam tahap ini peneliti melakukan anlisis terhadap materi dalam pelatihan. Peneliti menganalisis informasi yang diperoleh melalui diskusi dengan salah seorang Learning Development Coordinator pada PT. Circleka Indonesia Utama. Learning Development Coordinator dipilih sebagai narasumber karena Learning Development Coordinator merupakan pemateri sekaligus perancang pembelajaran untuk training basic. Learning Development Coordinator tersebut bernama Bapak Achmad Kurniawan S.Pd. Pengembang dan Learning Development CoordinatoR mendiskusikan terkait materi apa saja yang dapat dikembangkan kedalam pembelajaran online berdasarkan berbagai pertimbangan. Produk 
yang dihasilkan pada proses analisis materi ini adalah topik pembelajaran yang nantinya akan dikembangkan dalam bentuk pembelajaran online.

Tahap kedua adalah menyusun tujuan pembelajaran (set objective). Tujuan pembelajaran yang dikembangkan terbagi menjadi tujuan pembelajaran umum dan tujuan pembelajaran khusus. Rumusan tujuan dibuat berdasarkan analisis kebutuhan peserta pelatihan dan analisis materi.

Setelah rumusan tujuan selesai dirumuskan maka tahap selanjutnya adalah melakukan tahap pengembangan prototipe (construct prototype). Dalam tahap ini peneliti melakukan beberapa tahapan yaitu Membuat Content Map, Membuat naskah web dan mengembangkan produk Learning Object (LO).

\section{1) Membuat Content Map}

Pada tahap ini pengembang bersama dengan ahli materi menentukan jenis ragam pengetahuan dan menentukan tipe learning object (LO) atas topik materi yang akan dikembangkan.

2) Mengembangkan Naskah Web

Setelah mengembangkan Content Map, pengembang mengembangkan naskah web sebagai acuan dalam penyusunan pembelajaran pada online course

3) Mengembangkan Storyboard

Tahap selanjutnya pengembang mengembangkan storyboard video. Pengembangan storyboard dilakukan untuk menjadi acuan pengembang dalam proses produksi dan editing video pembelajaran.

4) Mengembangkan Produk Learning Object (LO)

Setelah mengembangkan naskah web, pengembang mengembangkan setiap LO degan melalui proses pegambilan gambar (shooting video), kemudian dilanjutkan dengan proses editing dengan menggunakan beberapa software yaitu Adobe After Effect CC 2017, Adibe Premiere Pro CC 2017, dan Microsoft Office Power Point 2019.

Pada tahap ini pengembang melakukan uj coba terhadap prototipe yang telah dikembangkan. Instrumen yang digunakan untuk uji coba prototipe ialah instrumen yang telah dikembangkan oleh Aprilia Putri Wijayanti, Mahasiswa Teknologi Pendidikan Angkatan 2014 dengan skripsi yang berjudul "Pengembangan Online Course Untuk Mata Kuliah Pemanfaatan Media dan Sumber Belajar Di Program Studi Teknologi Pendidikan Universitas Negeri Jakarta". Adapun validator intrumen penelitian tersebut yaitu Cecep Kustandi M,Pd.

Evaluasi formatif terhadap produk penelitian yang pertama dilakukan yaitu oleh ahli materi adalah orang yang memiliki kompetensi pada materi training basic yaitu Learning Development Coordinator PT. Circleka Indonesia Utama. Ahli materi pada penelitian pengembangan ini yaitu Achmad Kurniawan selaku Learning Development Coordinator PT.Circleka Indonesia Utama.

Selanjutnya yaitu ahli desain pembelajaran. Ahli desain pembelajaran adalah orang yang memiliki kompetensi pada pengembangan pembelajaran online. Ahli desain pembelajaran dilibatkan dalam review rancangan pembelajaran online pada training basic yaitu dosen Prodi Teknologi Pendidikan UNJ. Ahli desain pembelajaran pada penelitian pengembangan ini yaitu Drs. Robinson Situmorang, M.Pd selaku Dosen Prodi Teknologi Pendidikan Universitas Negeri Jakarta.

Selanjutnya yaitu ahli media. Ahli media pembelajaran yaitu orang yang memiliki kompetensi pada pengembangan media pembelajaran. Ahli media dilibatkan untuk review produk media pembelajaran pada pembelajaran online training basic. Ahli media pada penelitian pengembangan ini yaitu Cecep Kustandi, M.Pd selaku Dosen Prodi Teknologi Pendidikan Universitas Negeri Jakarta.

Kemudian pada tahap Uji coba. Tahap ini diakukan oleh pengguna untuk menguji produk LO pada penelitian ini di bagi menjadi dua segmen. Uji coba yang dilakukan menggunakan teknik one-toone evaluation dilakukan kepada 3 orang responden yang terdiri dari CSR yang sudah mengikuti Training Basic dan peserta Training Basic yang sedang melakukan proses rekrutmen. Kemudian dilanjutkan dengan uji coba small group dengan 9 responden yang terdiri dari para peserta Training Basic yang sedang melakukan proses rekrutmen. Kuisioner uji coba menggunakanskala likert berupa pertanyaan dengan dengan jawaban $1-4$. Jawaban akan di rata - rata dengan rumus.

Skor rata-rata $=\frac{\text { Jumlah keseluruhan skor }}{\text { Jumlah butir soal }} \times 100 \%$

setelah dapat nilai dari hasil rata - rata, untuk manafsirkan data kuantitatif menjadi data kualitatif digunakan acuan sebagai berikut :
$1,75-1,00$
= kurang baik
$2,50-1,76$
$3,25-2,51$
$3,26-4,00$
= cukup baik
$=$ baik
= sangat baik

Setelah produk diperbaiki hingga produk sudah memenuhi kriteria media pembelajaran yang baik menurut para ahli, maka produk yang dikembangkan dapat dikatakan sebagai final prototype. Produk atau prototipe final ini selanjutnya akan melalui proses installing ke dalam sistem untuk kemudian dapat digunakan oleh penyelenggara pada training basic di PT. Circleka Indonesia Utama.

\section{HASIL DAN PEMBAHASAN}

Pada artikel yang ditulis dari penelitian, maka di awal bagian hasil dan pembahasan didahului oleh keterangan pelaksanaan penelitian, yaitu (1) keterangan waktu penelitian, (2) durasi pelaksanaan penelitian, (3) informan atau responden yang diperoleh, dan (4) diakhiri dengan keterangan 
hal-hal yang akan dijelaskan pada beberapa paragraf setelahnya.

Penelitian pengembangan ini dilakukan 6 bulan terhitung dari Juli 2019. Adapun responden yang terlibat pada penelitian ini yaitu Customer Service Representative (CSR) Circle K dan calon CSR yang sedang menjalani proses rekrutmen atau Store Development Program (SDP). Produk yang dikembangkan dari penelitian pengembangan adalah learning object (LO) pada Training Basic PT. Circleka Indonesia Utama dimana pengembang membatasi $L O$ berupa video pembelajaran. Berdasarkan proses pengembangan Learning Object (LO), diperoleh produk LO melalui tahap pengembangan menggunakan model rapid prototyping. Adapun tahapan pada proses pengembangan LO yaitu Assess Needs and Analyze Content, Set Objectives, Construct Prototype (Design), Utilization Prototype (Research), dan Installing the Final System.

Adapun hasil penelitian sesuai dengan prosedur pengembangan model Rapid Prototyping. Pada tahap analisis kebutuhan (assess need), pengembang melakukan analisis peserta didik, kemampuan menggunakan IT dan mengakses jaringan internet. Adapun hasil yang diperoleh pada analisis kebutuhan tahap ini yaitu (1) Analisis Peserta Didik. Pada tahap ini pengembang menyebar kuisioner ke 30 calon karyawan Circle $\mathrm{K}$ yang terdiri dari 20 calon karyawan Circle K cabang Jakarta, 5 orang calon karyawan cabang Bandung dan 5 orang calon karyawan cabang Bandung. Ketiga region tersebut dipilih pengembang karna daerah tersebut merupakan region dengan angka turn over tertinggi. Berikut adalah informasi yang di dapat dari data yang dikumpulkan oleh pengembang.

1. Calon karyawan Circle $K$ pada umumnya berusia 19-22 Tahun.

2. Berdasarkan data yang diperoleh, $97 \%$ calon karyawan menggunakan smartphone dalam mengakses pembelajaran online.

Berdasarkan penelitian yang dilakukan $\mathrm{Ng}$ (2012) terhadap siswa usia (18-22), menemukan bahwa mereka yang tergolong dalam kelompok digital native ini 90\% memiliki akses tak terbatas pada smartphone. Adapun gaya belajar digital native dibatasi pada gaya belajar terkait dengan penggunaan teknologi informasi dan komunikasi dalam proses pembelajaran mereka. Jadi calon karyawan Circle $K$ merupakan kelompok digital native dimana memiliki akses pada penggunaan smartphone dan cenderung menggunakan teknologi informasi dan komunikasi dalam proses pembelajaran mereka. Data lengkapnya terlampir pada lampiran di penelitian pengembangan ini. (2) Analisis kemampuan menggunakan IT dan mengakses jaringan internet. Pada tahap ini pengembang mendapatkan informasi terkait kecenderungan kemampuan calon karyawan dalam menggunakan teknologi komputer dan jaringan internet.

1. Sebagian besar calon karyawan Circle K sudah pernah mengikuti training secara online. Hal ini menunjukan bahwa training online bukan lagi hal baru bagi mereka.

2. Sebagian besar calon karyawan terbiasa untuk mencari materi di internet sebagai sumber belajar utama maupun sumber belajar tambahan. Hal ini menunjukan bahwa sebagian besar calon karyawan terbiasa menggunakan perangkat untuk mengakses materi - materi yang mereka butuhkan secara mandiri. Data lengkapnya terlampir pada lampiran di penelitian pengembangan ini.

Kemudian pada tahap menentukan tujuan pembelajaran (set objective) pengembang melakukan analisis materi yang akan dikembangkan sebagai Learning Object (LO). Pada tahap ini, pengembang melakukan analisis bersama dengan Learning Development Coordinator PT. Circleka Indonesia Utama yaitu Achmad Kurniawan. Langkah pertama pengembang dan Learning Development Coordinator Circle K meninjau materi yang terdapat pada Training Basic Circle K.

Setelah melakukan diskusi dengan Learning Development Coordinator Circle K, Pengembang sepakat untuk mengembangkan beberapa materi sebagai Learning Object pada online course Training Basic Circle $\mathrm{K}$ dengan Pertimbangan pemilihan materi yaitu materi - materi yang bersifat praktis dan dapat langsung diterapkan oleh CSR di toko. Berikut adalah materi yang akan dikembangkan pengembang sebagai Learning Object (LO) pada online course Training Basic Circle K.

Tabel 2 Rancangan Pembelajaran Online Training Basic Circle K

\begin{tabular}{|c|c|c|}
\hline No. & $\begin{array}{l}\text { Pokok } \\
\text { Bahasan }\end{array}$ & Sub Pokok Bahasan \\
\hline \multirow{3}{*}{1} & \multirow{3}{*}{$\begin{array}{l}\text { Standar } \\
\text { Penampilan } \\
\text { CSR }\end{array}$} & Standar Penampilan CSR \\
\hline & & Standar Penampilan SL \\
\hline & & $\begin{array}{l}\text { Standar Penampilan CSR } \\
\text { FS }\end{array}$ \\
\hline \multirow[b]{2}{*}{2} & \multirow{2}{*}{$\begin{array}{l}\text { Prinsip } \\
\text { Pelayanan } \\
\text { Pelanggan }\end{array}$} & Prinsip WOWW Service \\
\hline & & $\begin{array}{l}\text { Prinsip Penanganan } \\
\text { Komplain Pelanggan }\end{array}$ \\
\hline
\end{tabular}

Setelah menentukan materi yang akan dikembangkan, pengembang menentukan tujuan pembelajaran sesuai dengan materi yang akan dikembangkan. Berdasarkan hasil analisis materi yang telah dilakukan sebelumnya, maka tujuan pembelajaran pada Training basic yaitu sebagai berikut.

Tujuan Pembelajaran Umum : Peserta Pelatihan mampu menjelaskan standar penampilan CSR di toko dan Prinsip Pelayanan Pelanggan. 
Tabel 2 Tujuan Khusus Pembelajaran Online Training Basic Circle K

\begin{tabular}{|c|c|c|}
\hline No. & Tujuan Khusus & $\begin{array}{ll}\text { Sub } & \text { Pokok } \\
\text { Bahasan } & \\
\end{array}$ \\
\hline \multirow{3}{*}{1} & \multirow{3}{*}{$\begin{array}{l}\text { Setelah mempelajari } \\
\text { materi tersebut, } \\
\text { setiap peserta } \\
\text { pelatihan dapat } \\
\text { menjelaskan Standar } \\
\text { Penampilan } \\
\text { Customer Service } \\
\text { Representative (CSR) } \\
\text { di toko Circle K }\end{array}$} & $\begin{array}{l}\text { Standar } \\
\text { Penampilan CSR }\end{array}$ \\
\hline & & $\begin{array}{l}\text { Standar } \\
\text { Penampilan SL }\end{array}$ \\
\hline & & $\begin{array}{l}\text { Standar } \\
\text { Penampilan CSR FS }\end{array}$ \\
\hline \multirow{2}{*}{2} & \multirow{2}{*}{$\begin{array}{l}\text { Setelah mempelajari } \\
\text { materi tersebut, } \\
\text { setiap peserta } \\
\text { pelatihan dapat } \\
\text { menjelaskan Prinsip } \\
\text { Pelayanan Pelanggan } \\
\text { di toko Circle K }\end{array}$} & $\begin{array}{l}\text { Prinsip WOWW } \\
\text { Service }\end{array}$ \\
\hline & & $\begin{array}{l}\text { Prinsip } \\
\text { Penanganan } \\
\text { Komplain } \\
\text { Pelanggan }\end{array}$ \\
\hline
\end{tabular}

Setelah rumusan tujuan selesai dirumuskan maka tahap selanjutnya adalah melakukan tahap pengembangan prototipe. Dalam tahap ini peneliti melakukan beberapa tahapan yaitu Membuat Content Map, Mengembangkan naskah web, mengembangkan storyboard video, mengembangkan video pembelajaran, Mengunggah dan menyusun Learning Object ke dalam Coursesite. Pada tahap pembuatan Content Map, pengembang melakukan chunking materi yang telah di dapat pada tahap analisis konten degan cara menentukan jenis ragam pengetahuan dan tipe learning object (LO). Hasil dari Chungking materi menghasilkan dua pokok bahasan dan lima sub pokok bahasaan atau materi inti. Masing - masing materi tersebut termasuk pada jenis ragam pengetahuan konsep, prinsip dan prosedur. Kemudian pemilhan media atau tipe learning object di fokuskan pada video.

Setelah mengembangkan Content Map, pengembang membuat naskah web. Naskah web dikembangkan sebagai acuan pengembang dalam mendesain pembelajaran sesuai dengan prinsip prinsip pengembangan pembelajaran online. Pada naskah pembelajaran online terdapat dua learning path. Learning path 1 yaitu standar penampilan Customer Service Representative (CSR) yang terdiri dari tiga Learning Object (LO) yaitu standar penampilan CSR, standar penampilan store leader (SL) dan standar penampilan CSR Food Service. Kemudian Learning Path 2 yaitu Prinsip Pelayanan
Pelanggan dengan dua learning object yaitu prinsip WOWW service dan prinsip penanganan komplain.

Tahap selanjutnya, pengembang melakukan pengembangan storyboard video pembelajaran. Pada saat mengembangkan storyboard, pengembang melakukannya bersama ahli materi yaitu Achmad Kurniawan selaku Learning Development Coordinator Circle K. Storyboard dikembangkan untuk menjadi acuan pada saat poses shooting dan editing video. Video pembelajaran pun terbagi menjadi 2 jenis. Video pada topik pertama yaitu standar penampilan CSR, dikembangkannya video animasi tanpa voice over (VO) dan video pada topik kedua yaitu prinsip pelayanan pelanggan membutuhkan shooting video dan voice over (VO). Data lengkapnya terlampir pada lampiran di penelitian pengembangan ini.

Setelah pembuatan storyboard selesai, Pengembang melakukan produksi video pembelajaran topik "Prinsip Pelayanan Pelanggan." Pengembang bersama ahli materi melakukan pengambilan gambar pada tanggal 20 - 21 September 2019, di toko Circle K Dago, Circle K Braga dan Circle K Pasir Kaliki, Bandung. Pengembang melibatkan 2 Talent yaitu Dita Kusuma dan Christoper Maulana sebagai pemeran utama (New Joiner CSR Circle K). Bapak Widianto Pratama, Ibu Siska Sugantar, Dede dan Tia sebagai Figuran. Kemudian pada pengambilan gambar dibantu oleh tim produksi yaitu akhmad jaelani, heggy wiyoko dan hafiz.

Tahap selanjutnya perekaman audio / voice over pada video. Voice Over pada Video pembelajaran dibantu oleh Irine Nasution yang direkam menggunakan microphone condenser. Voice Over yang direkam mengacu pada narasi yang dibuat oleh pengembang dengan format akhir (.wav). Setelah pengambilan gambar dan perekaman audio selesai, pengembang melakukan tahap desain produk learning object (LO) berupa video pembelajaran. Berikut adalah proses yang dilakukan oleh pengembang dalam mengembangkan video pembelajaran. Insert gambar dan motion pada video.

Pengembang melakukan insert gambar pada video pembelajaran topik standar penampilan CSR menggunakan aplikasi Microsoft Office Power Point 2019. Tahap pertama pengembang melakukan insert gambar dan mendesain slide presentasi sesuai dengan storyboard yang telah di kembangkan. Kemudian pengembang menambahkan motion pada animasi yang telah dibuat dan menyesuaikan durasi dengan teks yang muncul. Setelah itu pengembang melakukan proses export file dengan format .mp4 Selanjutnya membuat bumper video. Pengembang menggunakan software Adobe After Effect Pro CC 2017 untuk membuat bumper pada video pembelajaran. Berikut proses editing bumper video pembelajaran Training basic Circle K. Pada proses pengembangan video pembelajaran, pengembang menggunakan software Adobe Premiere Pro CC 2017 dengan hasil akhir format .mp4. Software ini 
digunakan untuk mengembangkan video pembelajaran pada topik prinsip pelayanan pelanggan. Proses pengembangan video dimulai dari memasukan video yang dihasilkan pada proses shooting video sesuai dengan urutan didalam storyboard. Kemudian pengembang mnyesuaikan voice over berdasarkan urutan dan durai video pada storyboard video.

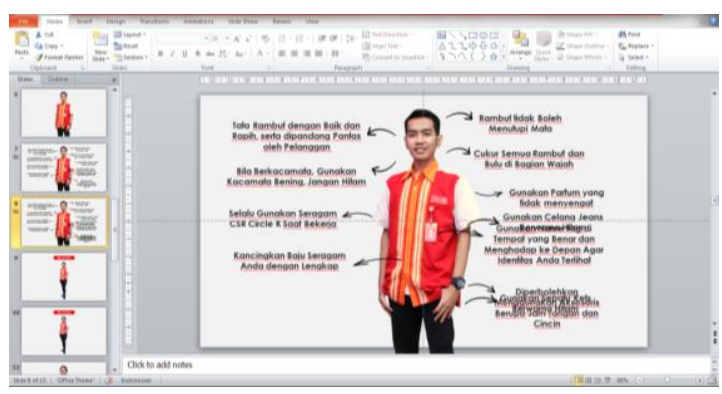

Gambar 4.3 Slide video standar penampilan CSR

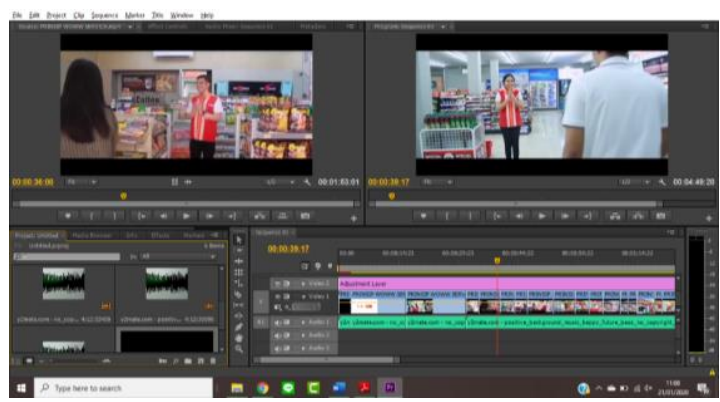

Gambar 4.3 Proses Pembuatan Video Pembelajaran

Setelah produk selesai dikembangkan, selanjutnya pengembang mengunggah Learning Object yang telah dikembangkan ke dalam platform moodle sesuai dengan naskah web. Pengembang menggunakan tema fordson pada tampilan moodle dan Tiles Format sebagai course format yang diunduh pada moodle plugin. Berikut adalah proses penyusunan dan pengembangan Learning Object kedalam platform moodle. (1) Mengembangkan homepage Tahap pertama, pengembang membuat homepage sebagai tampilan awal ketika peserta mengakses elearning.circlekonline.com. (2) Membuat course baru. Tahap selanjutnya pengembang membuat course baru (new course). Tahap ini mengacu pada naskah web yang telah dikembangkan sebelumnya. Mengunggah Learning Object

Tahap selanjutnya yaitu mengunggah learning object dan menyesuaikannya dengan beberapa tools yang ada di platform moodle.

a. Tools Label : Tools ini digunakan oleh pengembang untuk menyematkan tujuan pembelajaran pada setiap topik. b. Tools Page : tools ini digunakan untuk menunggah video pembelajaran. Pengembang terlebih dahulu mengunggah video kedalam youtube kemudian disematkan kedalam platform moodle dengan tools page.

c. Tools Assignment : tools ini digunakan oleh pengembang sebagai latihan peserta pelatihan. Pengembang membuat soal latihan untuk kemudian peserta diminta untuk mengerjakan dan mengunggah tugasnya kedalam platform dengan format .doc.

d. Tools Forum : pada tools ini pengembang manfaatkan untuk forum diskusi peserta pelatihan. Pada forum ini terdapat topik sesuai dengan materi pelatihan untuk didiskusikan oleh para peserta pelatihan.

e. Tools Quiz : Tools ini dimanfaatkan oleh pengembang untuk melakukan tes sumatif guna menilai pemahaman peserta pelatihan seteah mengikuti pelatihan online.

Tahap Selanjutnya yaitu Utilize Prototype. Pada tahap ini pengembang melakukan uji coba produk Learning Object (LO) yang telah dikembangkan untuk melihat kualitas dari produk tersebut. Teknik evaluasi yang digunakan oleh pengembang yaitu review ahli (ahli materi, ahli desain pembelajaran, ahli media) dan uji coba pengguna (one-to-one dan small group).Berikut adalah hasil dari tahap evaluasi produk LO (1) Review Ahli Materi. Ahli materi yang membantu mereview produk Learning Object (LO) yaitu Achmad Kurniawan sebagai Learning Development Coordinator PT Circleka Indonesia Utama. Berikut adalah hasil review oleh ahli materi. Berdasarkan data tersebut, Ahli materi memberikan penilaian pada produk LO dengan rata - rata 3,56, dengan kategori sangat baik

Tabel 5 Nilai Review Ahli Materi

\begin{tabular}{|l|c|c|}
\hline \multicolumn{1}{|c|}{ Aspek } & Nilai & Rata - rata \\
\hline Pembelajaran & 3,50 & \\
\cline { 1 - 2 } Materi & 3,58 & \multirow{2}{*}{3,56} \\
\hline $\begin{array}{l}\text { Bahasa dan } \\
\text { Komunikasi }\end{array}$ & 3,33 & \\
\hline
\end{tabular}

Tahap selanjutnya yaitu review ahli media. Ahli media yang membantu mereview produk Learning Object (LO) yaitu Cecep Kustandi, M.Pd selaku Dosen di Prodi Teknologi Pendidikan UNJ.. Berdasarkan data tersebut, Ahli media memberikan penilaian pada produk LO dengan rata - rata 3,49, dengan kategori sangat baik. 
Rafii Ramandika Yudhoyono | JPI/Vol.o3/No.o1/202o| H. 36 - 44

Tabel 6 Nilai Review Ahli Media

\begin{tabular}{|l|c|c|}
\hline \multicolumn{1}{|c|}{ Aspek } & Nilai & Rata - rata \\
\hline Tampilan & 3,44 & \\
\cline { 1 - 2 } $\begin{array}{l}\text { Pemanfaatan } \\
\text { Media }\end{array}$ & 3,25 & \\
\hline $\begin{array}{l}\text { Penyajian (video } \\
\text { \& Animasi) }\end{array}$ & 3,80 & \\
\hline
\end{tabular}

Selanjutnya review ahli desain pembelajaran. ahli desain pembelajaran yang membantu mereview produk Learning Object (LO) yaitu drs. robinson situmorang, m.pd selaku dosen di Prodi Teknologi Pendidikan UNJ.

Tabel 7 Nilai Review Ahli Desain Pembelajaran

\begin{tabular}{|l|c|c|}
\hline \multicolumn{1}{|c|}{ Aspek } & Nilai & Rata - rata \\
\hline Pembelajaran & 3,30 & \\
\hline Tampilan & 3,40 & \multirow{2}{*}{3,36} \\
\cline { 1 - 2 } $\begin{array}{l}\text { Aspek Program/ } \\
\text { Kompabiltas }\end{array}$ & 3,25 & \\
\hline $\begin{array}{l}\text { Bahasa dan } \\
\text { Komunikasi }\end{array}$ & 3,50 & \\
\hline
\end{tabular}

Tahap selanjutnya yaitu uji coba produk one-to-one evaluation. Pada tahap ini pengembang melibatkan 3 responden yaitu CSR PT Circleka Indonesia Utama. Berdasarkan data tersebut, produk LO ini menghasilkan nilai rata - rata 3,20, dengan kategori Baik.

Tabel 7 Nilai Uji coba one-to-one evaluation

\begin{tabular}{|l|c|c|}
\hline \multicolumn{1}{|c|}{ Aspek } & Nilai & Rata - rata \\
\hline Pembelajaran & 3,41 & \\
\hline Tampilan & 3,25 & \multirow{2}{*}{3,20} \\
\cline { 1 - 2 } $\begin{array}{l}\text { Aspek Program/ } \\
\text { Kompabiltas }\end{array}$ & $\mathbf{2 , 9 5}$ & \\
\hline $\begin{array}{l}\text { Bahasa dan } \\
\text { Komunikasi }\end{array}$ & 3,21 & \\
\hline
\end{tabular}

Tahap selanjutnya yaitu uji coba produk small group evaluation Pada tahap ini pengembang melibatkan 9 responden yaitu calon CSR PT Circleka Indonesia Utama yang telah mengikuti training basic. Berdasarkan data tersebut, produk LO ini menghasilkan nilai rata - rata 3,49, dengan kategori Sangat Baik.
Tabel 7 Nilai uji coba small group evaluaton

\begin{tabular}{|l|c|c|}
\hline \multicolumn{1}{|c|}{ Aspek } & Nilai & Rata - rata \\
\hline Pembelajaran & 3,44 & \\
\hline Tampilan & 3,58 & \multirow{2}{*}{3,49} \\
\cline { 1 - 2 } $\begin{array}{l}\text { Aspek Program/ } \\
\text { Kompabiltas }\end{array}$ & 2,50 & \\
\hline $\begin{array}{l}\text { Bahasa dan } \\
\text { Komunikasi }\end{array}$ & 3,46 & \\
\hline
\end{tabular}

Tahap berikutnya yaitu tahap installing the final system. Tahap ini merupakan tahap akhir pengembangan produk yaitu melakukan Install produk LO yang telah di perbaiki ke dalam sistem.

\section{SIMPULAN}

Produk pengembangan Learning Object pada Training Basic di PT. Circleka Indonesia utama dapat dimanfaatkan oleh perusahaan sebagai bagian dari Store Development Program $(S D P)$. Produk ini juga dapat menjadi acuan program pengembangan karyawan di jenjang lain.

\section{UCAPAN TERIMA KASIH}

Peneliti mengucapkan terima kasih kepada Bapak Mulyadi, M. Pd sebagai dosen pembimbing 1 yang telah meluangkan waktu untuk membimbing peneliti dalam menyelesaikan penelitian ini. Peneliti juga mengucapkan terima kasih kepada Bapak Kunto Imbar M.Pd sebagai dosen pembimbing 2 yang selalu memberikan masukan untuk penelitian ini. Tidak lupa peneliti ucapkan terima kasih kepada para expert review. Terakhir peneliti ucapkan terima kasih kepada PT. Circleka Indonesia Utama yang mengizinkan peneliti melakukan penelitian ini. 


\section{DAFTAR PUSTAKA}

Atmodiwiri, Soebagio. (1993). Manajemen Praktis (Pedoman Praktis Bagi Penyelenggaraan Training). Jakarta: Balai Pustaka.

Horton, W. (2010). E-Learning by Design. United States of America: Pfeiffer An Imprint of Wiley.

Keramida, M. The importance of Learning Objects in instructional design for elearning. Instructional design, 1-10.

Moekijat. (1991). Pelatihan dan Pengembangan Sumber Daya Manusia. Bandung: PT Mandar Maju.

Prawiradilaga, D. S. (2008). Prinsip Desain Pembelajaran. Jakarta: Kencana Prenada Media Group.

Prawiradilaga, D. S. (2013). Mozaik Teknologi Pendidikan: E-learning. Jakarta: Kencana Prenada Media Group.

Prawiradilaga, D. S. (2012). Wawasan Teknologi Pendidikan. Jakarta: Kencana Prenada Media Group.

Pribadi, Benny A. (2014). Desain Pengembangan Program Pelatihan Berbasis Kompetensi: Implementasi Model ADDIE. Jakarta: Kencana.

Purwani, Istiana. (2016). Gaya Belajar dan Perilaku Digital Native Terhadap Teknologi Digital dan Perpustakaan. Bandung:UndpadPress.

Seels, Barbara \& Richey, Rita. (1994). Teknologi Pembelajaran: Definisi dan Kawasannya. Jakarta: UNJ.

Situmorang, R. et al. (2005). Desain Pembelajaran. Jakarta: UT.

Sugiyono. (2011). Metode Penelitian Kuantitatif Kualitatif dan REDD. Jakarta: Alfabeta.

Suparman, Atwi (1997). Desain Instruksional. Jakarta: PAU PPAI Universitas Terbuka.
Wiley, D. A. (2002). Connecting Learning Objects to Instructional Design Theory: a Definition, a Metaphor, and a Taxonomy. IN: Agency for instructional technology (AECT).

Wiley, D. A. (2002). The instructional use of Learning Objects. Bloomington, Indiana: AECT.

Yaumi, M. (2013). Prinsip-Prinsip Desain Pembelajaran. Jakarta: Kencana.

Guy Boulet, Rapid prototyping: an efficient way to collaboratively design and develop elearning content (Journal of Navy eLearning center of Excellence),

S. D. Tripp and B. Bichelmeyer, Rapid Prototyping: An Alternative Instructional Design Strategy (http://ocw.metu.edu.tr/pluginfile.php/ $5484 / \mathrm{mod}$ resource/content $/ 2 /$ Rapidprototype.ppt) 